\title{
Job Satisfaction, Organizational Commitment and OCB: An Examination of Three Employees' Behaviors in Unionized Work Context
}

\author{
Dhammika K.A.S. ${ }^{1}$ \\ Department of Human Resource Management \\ University of Kelaniya \\ Sri Lanka \\ kasdhammika@yahoo.com
}

\begin{abstract}
One of the characteristics of the industrial relation climate of Sri Lanka is that it has high unionized working environment. This high unionization of employees is claimed to affect number of behavioral factors associated with employees. Though the effect of unionization on organizations' outcomes have been carried out, researches in this regard in Sri Lankan context are rare. This study is aimed at examining the effect of employees' unionization on employees' behaviors. The sample of this study is consisted of 380 public and private sector employees and it was drawn by using the stratified random sampling method. Data was collected by administering questionnaires. The data was analyzed with Structural Equation Modeling (SEM). It was found that unionization has a negative effect on the work related behavior of employees. Further it was revealed that the negative effect of unionization is higher in the public sector than in the private sectors.
\end{abstract}

Keywords: Employee Unionization, Union Commitment, Union Politicization, Work Related Behaviors

\section{Introduction}

Organizations having employees' unions in them experience a particular industrial relation climate. This is resultant of the possible effect of unionization on the behavior of employees and their work outcomes. Though, researchers have examined the effect of unionization on various employees' work related behavior such as job satisfaction, performance, OC etc., there is a dearth of empirical studies which have considered the effect of unionization on these

(D) http://orcid.org/0000-0002-3998-8066 
variables taking them together. Such an examination will shed more light on the unionization and its effects in organizational context. On the other hand, most of these studies have been carried out in the western context and few reported research can be found in Sri Lankan context. Given the fact that both the private and public sector organizations in Sri Lanka are highly unionized, an empirical study is warranted in these aspects. Therefore, the objective of the present study is to examine the effect of unionization on three employees' work related behaviors, namely job satisfaction, organizational commitment and organizational citizenship behaviors, and compares the effect of unionization across the two sectors. This will increase the understanding of the unionization and its effect by the managers of these organizations from which they can manage their industrial relation climate effectively.

\section{Background of the Issue}

Some of the activities of employees' union such as taking part in collective bargaining, leading political actions, fighting for community welfare and organizing recreational activities create a particular industrial relation climate in organization (Berkowitz, 1954). As a result, it may bring some implications not only to the management but also to the behaviors of employees of these organizations. Researchers have examined this implication of employees' unionization empirically over the past years. For instance, it has been found that it creates a challenging organizational context for the managers of these organizations. The higher unionization of employees and politicization of employee unions have brought severe managerial and economic implications and these implications are two in nature (Dhammika, Ahamed, \& Sam, 2013). The productivity level of these organizations has been hampered with the high unionization of employees (Cabral, 1992; Kumarashamy, Amarasisri, Dalluwaththa, Ramyasisi, \& Guruge, 1997). Further, this high unionization has created a hostile relationship between the management and employees (Jinadasa \& Opatha, 1999) and an increase in industrial disputes.

High unionization of employees also has been found to reduces mangers' discretion in decision making (Murillo \& Ronconi, 2004), hinders the implementation of higher performance working practices (Liu, Guthrie, Flood, \& MaCcurtain, 2009), and impedes organizational change and development strategies (Iverson \& Kuruvilla, 1995). For instance, Laroche and Wechtler (2011) found that unionization of employees was associated with poor financial performance, and Doucouliagos and Loroche (2009) claimed a negative effect of unionization on a firm's profit. 
The above description highlights the fact that understanding of employee unionization, particularly the impact of employee unionization is critical for the effective management of the organizations in Sri Lanka. This study questions itself whether employees' unionization has any impact on employees' outcomes in a unionized work context. It set the objective to explore the impact of unionization on employees' outcomes. Therefore, the study examined the impact of employee unionization on three major employee outcomes namely, job satisfaction, organizational commitment, and organizational citizenship behavior of public and private sector employees in Sri Lanka.

\section{Job Satisfaction in Unionized Work Environment}

Job satisfaction (JS) has been a one of the mostly researched on in the field of behavioral science over the past few years. Many factors have been identified as antecedents and consequences of JB. Among the various factors affecting to the job satisfaction of employees, the nature of the work context has been given a particular place. However, the job satisfaction of employees working in a unionized environment has been generally claimed to be low. Empirical examination of the effect of employee unionization on job satisfaction has come in a long way (Shan, Hu, Zhi, Zhang, \& Zhang, 2016). Job dissatisfaction has been identified as one of the factor for employees to join with unions as active members (Charlwood 2002: Hammer \& Avgar, 2005). A number of explanations have been offered as to why union members are less satisfied with their jobs. One such explanation is the exit-hypothesis suggested by Freeman and Medolf (1984), which claims that dissatisfaction of union members does not come from an actual evaluation of either the job or job outcome, but comes from the psychological process seeking redress over job factors, which become an attitude of job dissatisfaction. Another view of job dissatisfaction is that, because union leaders often stress the negative aspects of jobs with the aim of attracting and sustaining members, it creates negative attitudes in union members regarding their job, resulting in job dissatisfaction (Barling, Clive, \& Kelloway, 1992). The recent attribution of union members' dissatisfaction has been to the poor industrial relationship climate due to high level of management resistance to unions and the militant attitude of union leaders over bargaining issues (Kleiner, 2002). Authors have claimed that poor industrial relations climate reduces the possibility of seeking redresses for job-related matters, which result in job dissatisfaction in union employees. Despite this theoretical explanation of the relationship of unionization to job satisfaction, empirical studies have recorded mixed results (Bryson, Lorenzo, \& Laidio, 2003). 
In a study with survey data, Kochan and David (1981) found a positive effect of union membership on some job aspects such as pay, benefits, and job security but negative effects on satisfaction with other job aspects like, the relationship with supervisors, promotion opportunities, resources, and information available for the job. This finding is inconsistence with the claim of Berger, Crag and John (1983) who argued that unions were emphasising matters such as pay, benefits and working conditions, which bring immediate satisfaction to members. However, unions pay less attention to job aspects such as industrial relations and promotions. This may result in job satisfaction in members with respect to pay and benifts but not with other facets of the job.

\section{Organizational Commitment and Unionization}

Organizational commitment (OC) is one of the employees' behavioral outcomes subjective to focus of researchers in the field of management over the past several years. Organizational commitment was simply defined as the 'binding of an individual to an organization' (Gordon et al., 1980: 480). Anyway, a comprehensive definition for OC was presented by Meyer, Allen and Smith (1993) with the identifying three components of it, namely, affective, continuance, and normative commitment. One question associated with OC of unionized employees is whether they are committed to the organization they work or to the union they are attached (Thacker, 2015). It might be expected that commitment to organization and to union would be a source of role conflict, involving cognitive dissonance, particularly if union and employer are seen to be in conflict (Festinger, 1957). However, researchers have provided two situations namely as unilateral and dual commitment of employees. Dual commitment is defined as a psychological state that exists in a worker holding a positive attachment to both employer and union (Stagner \& Rosen, 1965) whereas unilateral commitment results when employees perceive that either the organization or union is instrumental in achieving their job-related goals (Stanger \& Rosen, 1965). Unionization literature provides adequate evidence for the relationship between union and organizational commitment of employees.

The relationship between OC and union commitment (UC) depends on whether there is a dual commitment situation or unilateral situation. In the case of dual commitment scenario, a positive relationship exists between union and organizational commitment whereas in unilateral situation, the relationship tends to be negative. Further, the level of commitment to the union however depends on the support and facilitation provided to employees by the union. 
Thacker, (2015) posits that when the ability of the union to provide support is reduced, it reduces the employees' obligation to the union.

\section{Organizational Citizenship Behavior (OCB) and Unionization}

OCB is referred as behaviors exhibited by employees in organizations which are not a required for the formal job execution, but is beneficial for the organization (Organ, 1997). Such types of behaviors are beneficial to the organization since it creates a positive psychological and social organizational climate (Belino, Harvey, Hsiung, \& LePine, 2015). Some of the OCB behaviors identified by researchers are helping and mentoring coworkers, getting involved and keeping well informed about the organization, speaking up and encouraging others, volunteering to take on additional responsibilities, and so forth, and they are evaluated more favorably by their supervisors for doing (Whiting, Podsakoff, \& Pierce, 2008). However, higher level of OCB among employees would be somewhat problematic to the organization. Bolino et al., (2015) claims that OCB involves the choice to invest cognitive, emotional, and physical resources in activities that go beyond what is technically required, and when these resources are scarce, an internal tension is created whereby concerns regarding the fairness and utility of engaging in these specific activities start to weigh more heavily on the individual, resulting in feelings of fatigue with regard to these specific behaviors. This has been referred as citizenship fatigue, which is defined as a state in which feeling worn out, tired, or on edge is attributed to engaging in OCB (Bolino, et al., 2015).

The OCB behaviors of unionized employees have been a particular curiosity for researchers since there is a dual commitment scenario in unionized work context. It claims that there would be dual citizenship behavior of unionized employees (Dhammika, 2014). That is employees may exhibit citizenship behavior towards both the organization and union. Union Citizenship Behaviors (UCBs) is defined as voluntary and contributing to the union's functions, but are not explicitly required or rewarded by the union (Twigg et al., 2008). They are activities of union members that would be considered going above and beyond the call of duty and that are not directly rewarded by the union (Skarlicki \& Latham, 1996). It is clear from these definitions that UCB is concept derived from the studies on organizational citizenship behavior. Accordingly, if member of a union exhibit an engagement in union activities that are not expected otherwise, they can be seen as UCB. 
The association of OCB and UCB is resulted of few organizational factors operating in organizations. Organizational justice is one of the factors affecting to the level of OCB and UCB in unionized organizations. Workplace justice consists of distributive justice and procedural justice (Aryee \& Chay, 2001). Distributive justice represents the fairness of distribution of resource among members of the organization and the criteria used for that. On the other hand, procedural justice means fairness of the process and procedure in the organization (Folger \& Greenberg, 1985). Since employee union activities bear some implication for both distributive and procedural justice, for instance involving in grievances handling and disciplinary inquiries, union contributes to the distributive and procedural justice. Therefore, it can be argued that unionized employees may engage in organizational and union citizenship behavior unilaterally or multi laterally depending on the context.

\section{Hypotheses of the Study}

Based on the above empirical accounts, the hypotheses of this study were formulated as,

$\mathbf{H}_{1}$ : There is a negative impact of employee unionization on the job satisfaction of employees.

H2: There is a negative impact of employee unionization on the organizational commitment of employees.

H3: There is a negative impact of employee unionization on the performance of employees.

H4: There is a negative impact of employee unionization on the organizational citizenship behavior of employees.

\section{Methodology}

\section{Sample}

The sample of this study is consisted of 380 public and private sector employees belonging to the category of Clerical and Related Workers from banking, manufacturing and transport sector. Individuals for the sample were selected using stratified sampling method. First, the number of respondents from each organization was decided proportionately and then respondents from each organization were selected on availability based on the visit to each organization. 
Questionnaires were distributed among the respondents personally with the assistance of research assistants. It is expected to complete the data collection as two phases. In the first phase, the questionnaire will be administered among 100 respondents as a pilot study, and the data of it will be used to assess the reliability and validity of the instrument. In the phrase two, after the necessary amendments based on the pilot study, the questionnaire will be administered among the rest of the sample.

\section{Data Collection}

Data of the study was collected from the number of completed questionnaires collected from the study. Out of 100 questionnaires distributed among the respondents in the pilot study, 88 questionnaires were returned. In the main survey, it was able to collect 222 questionnaires. As a result, the data was collected from the 300 questionnaires collected from the survey.

\section{Measurements}

\section{Employee Unionization}

Employee unionization was measured with two dimensions namely union commitment and union politicization. Union commitment was assessed with the 11 items union commitment measurement of Conlon and Gallagher (1987). Some of the items of the measure are "I am willing to put in a grate deal of efforts beyond that is normaly expected in order to help this union to be successful", "I feel little loyalty to this union”. Items of the instrument are scaled on five point Likert's scale ranging from 1 ( Strongly Disagree) to 5 (Strongly Agree). Union politicization measure was adapted from two measures so as to incorporate both political instrumentality (Fiorito, 1987) and political belief dimensions (Charlwood, 2002: Boxall et al., 2006). The CFA of the measuremnt model of EU recorded a good model fit. $(\chi 2=22.3$, $d f=2, \mathrm{CFI}=.954$, and RMSEA $=.072$ ).

\section{Job Satisfaction}

Job satisfaction is adapted from the Minnesota Satisfaction Questionnaire (MSQ) short form first developed by Weiss, Dawis, England, and Lofquist (1967) and taken from Wlliams \& Anderson, (1991). It measures job satisfaction with intrinsic, extrinsic aspects and general satisfaction of the job. Responses on items are rated on five point Likert scale from 1 (not satisfied ) to 5 ( extreamely satisfied ). MSQ has been used in number of studies to measure the job satisfaction of employeesdue to its higher reliability and validity (Al-Hussami, 2008; 
Nguni et al., 2006). The confirmatorty Factor analysis (CFA) of the measurement model of JS confirm the validity and reliabilitry $(\chi 2=112.8, d f=5, \mathrm{CFI}=.910$, and RMSEA $=.073$ ).

\section{Organizational Commitment}

To measure commitment, 12 items organizational commitment measurement of O'Reilly \& Chatman, (1986) is adapted. Some of the items are "if the values of this organization were different, I would not be as attached to this organization", "The reason I prefer this organization is because of what it stands for its value". The items of the measure are anchored with five point scale from 1 (Strongly Disgree) to 5 (Strongly Agree). The measuremnt model for the OC with CFA analysis recorded a accepatable level of model fit with the data $(\chi 2=32.4, d f=2$, $\mathrm{CFI}=.92$, and RMSEA =.0.061) indicating a higher level of reliability and validity.

\section{Organizational Citizenship Behavior}

Organizational Citizenship Behaviors was assessed with 24-items OCB scale developed by (Podsakoff, et al. 1990). This measurement assesses the five dimensions of OCB proposed by Organ, (1997). These dimensions were altruism, conscientiousness, courtesy, sportsmanship and civic virtue. The responses were scaled form 1 (Strongly Disagree) to 5 (Strongly Agree). Some of the items of the measure are "I help others who have heavy work load', "I believe in giving an honest day's work for an honest day's pay". The items of the measure are anchored with five point scale from 1 (Strongly Disgree) to 5 (Strongly Agree). The CFA analysis of the measure revealded a satisfactory level $(\chi 2=209.4, d f=9, \mathrm{CFI}=.091$, and RMSEA $=0.063)$.

\section{Data Analysis}

The data of this study was analyzed with Structural Equation Modeling (SEM) with AMOS statistical analytical package. This is based on the fact that SEM facilitates the estimating of total, direct and indirect effect of variables which will produce more detailed elaboration on the impact of employee unionization on the aforesaid employee outcomes.

\section{Finding and Hypotheses Testing}

\section{Background of the Sample Respondents}

Some background information on the sample respondents was collected with aim of understanding the nature of the sample. This information was related to six aspects of the 
respondents' employment, namely, gender, age, educational background, job experience, tenure, and period of union membership.

The majority of the sample respondents were male accounting for $65.7 \%$ of the sample and female percentage was $34.3 \%$. The middle age catetory had $74.2 \%$ of the respondents with ages ranging from 30 to 50 years. The percentage of young respondents with ages ranging from 20 to 30 years was $21.1 \%$, and $4.7 \%$ of the sample had respondents who were more than 50 -years old. Therefore, the sample is consisted of relatively young respondents.

Respondents came from a diverse educational background. The sample had $16.1 \%$ with G.C.E (O/L) qualification. The majority (45.8\%) had G.C.E (A/L) qualification; $27.6 \%$ and $10.5 \%$ of the respondents had graduate or postgraduate qualification respectively. This situation is expected because the entry qualification of clerical and related worker catergory is just G.C.E $(\mathrm{O} / \mathrm{L})$ qualification.

Further, a large percentage of respondents $(58.7 \%)$ had a work experience ranging from 5 to 10 years in their positions. The sample had $24.2 \%$ with less than 5 years work experience, and $16.6 \%$ of the sample recorded 10 to 15 years of work experience. Only .5\% of respondents have a work experience of more than 15 years.

The number of years served in the present organization by the respondents was another bit of background information. The majority (47.9\%) of them had a tenure period of from 1 to 5 years in the present organization; $35.3 \%$ had from 6 to 10 years working period in the present organization, and only $3.1 \%$ had served more than ten years in the present organization. A few, $13.7 \%$, had served less than one year in the present organization.

The number of years of union membership of the respondents was also considered. The average tenure of the union membership was 5.25 years. Broken down in to groups, $40.3 \%$ of the sample recorded a period of from 6 to 10 years of union membership while $21.5 \%$ recorded more than 10 years of being a union member. Further, $29.5 \%$ of the respondents had from 1 to 5 years membership period. Only $8.7 \%$ of the sample had a union membership with less than one year.

\section{Descriptive Statistics}

A preliminary understanding on the nature of the data set collected can be gained by looking at the central tendencies of the data. The following table contains minimum, maximum, mean and standard deviation values of each variable of the study. 
Table 1: Descriptive Statistics of the Sample Data

\begin{tabular}{lccccc}
\hline Variable & $\mathbf{N}$ & Minimum & Maximum & Mean & Std.Deviation \\
\hline OCB & 300 & 1.58 & 4.75 & 3.57 & 1.51 \\
\hline Job satisfaction & 300 & 1.65 & 4.40 & 3.38 & 1.53 \\
\hline Employees & 300 & 2.69 & 4.58 & 3.68 & 1.39 \\
Performance & & & & & \\
\hline Organizational & 300 & 1.25 & 4.33 & 3.45 & 1.54 \\
Commitment & & & & & \\
\hline Union Commitment & 300 & 1.88 & 4.42 & 3.36 & 1.45 \\
\hline Union Politicization & 380 & 2.33 & 4.47 & 3.39 & 1.42 \\
\hline
\end{tabular}

Source: Survey Data

Table 1 clearly shows that data on measured variable was dispersed adequately so that it fits for the analytical purpose. OCB scored a mean value of 3.57 with a standard deviation of 1.51 , having minimum value of 1.58 and maximum value of 4.75 . On the other hand, job satisfaction had a mean value of 3.38 with a standard deviation of 1.53 and 1.65 minimum and 4.40 maximum values. The mean value of employee performance was 3.68 with a standard deviation of 1.39 having a 2.69 minimum and 4.58 maximum values. Organizational commitment, union commitment and union politicization measures centered on a mean value of $3.45,3.36$, and 3.39 with standard deviation values of $1.54,145$, and 1.42 respectively. Further, the minimum values and maximum values for these variables ranged from 1.25 to $4.33,1.88$ to 4.42 and 2.33 to 4.47 respectively.

\section{Preliminary Correlation Analysis}

A preliminary correlation analysis is done with the aim of identifying whether a satisfactory level of correlation exists between the variables so that it can proceed with further analysis. Table 2 shows the results of this preliminary correlation analysis. 
Table 2: Correlation Coeffcients between the Variables of the study

\begin{tabular}{lllllll}
\hline & 1 & 2 & 3 & 4 & 5 & 6 \\
\hline 1.OCB & 1.000 & & & & & \\
\hline 2.Performance & $.468^{* *}$ & 1.000 & & & & \\
\hline 3.Jobsatisfaction & $.457^{* *}$ & $-.113^{*}$ & 1.000 & & & \\
\hline 4.Commitment & $.259^{* *}$ & $.185^{* *}$ & $.187^{* *}$ & 1.000 & & \\
\hline 5.Unioncommitment & $.120^{*}$ & $.303^{*}$ & $-.156^{*}$ & $-.131^{*}$ & 1.000 & \\
\hline 6.Unionpoliticization & -.002 & $-.103^{*}$ & .096 & -.013 & -.003 & 1.000 \\
\hline
\end{tabular}

*Significant at .050

**Significant at .001

Source: Survey Data

Table 2 gives the results of the preliminary correlation analysis between the variables of the study. All variables except union politicization were found to be associated with each other to a significant proportion. OCB correlated with performance, job satisfaction, organizational commitment and union commitment positively $(\mathrm{r}=.468, .457$, and .259 , and .120). However, job satisfaction was found to be correlated with performance negatively $(r=-.133)$. Union commitment was associated with employee outcomes variables negatively ( $\mathrm{r}=-.156,-.131$, and$.170)$ and associated with other variables ( $\mathrm{r}=.120$, and.303). Union politicization was not correlated with any other variables significantly.

From this preliminary correlation analysis, it is evident that variables were correlated with each other so that it can be analyzed further with the aim of hypotheses testing. This analysis also provided strong backup for the hypothesis of negative effect of union commitment and union politicization. Union commitment was correlated with both criterion variables and outcomes variables of the study while union politicization had no such association.

\section{Measurement Models}

The measurement models of the each varibale were tested as to assess their validity. the measurement model for job satisfaction with five item parcels recorded adequate fit with $\chi 2$ $=112.8, d f=5, \mathrm{CFI}=.910$, and RMSEA $=.073$. Other measurement models of organizational commitment with four parcels, union commitment with four parcels and union politicization with five parcels were fitted with the data satisfactoraly $(\chi 2=32.4, d f=2, \mathrm{CFI}=.92$, and RMSEA $=.0 .061, \chi 2=22.3, d f=2, \mathrm{CFI}=.954$, and RMSEA $=.072$, and $\chi 2=65, d f=5, \mathrm{CFI}=.911$, and 
RMSEA =0.076). The measurement model of OCB with five dimensions too achieved an adequate level of model fit with $\chi 2=209.4, d f=9, \mathrm{CFI}=.091$, and RMSEA $=0.063$. These tests showed the validity of the item parcells formulated as the indicators of the variables of the measurement model, because all parcells were regressed with respective variable adequately and acheived an adequate model fit statistics with the data.

\section{Direct Effects Estimated}

A model testing procedure was done in line with the procedure of the SEM with the aim of assessing the direct effect of variables of the study. The following figure depicts the esmiated values on the parths depected by the model.

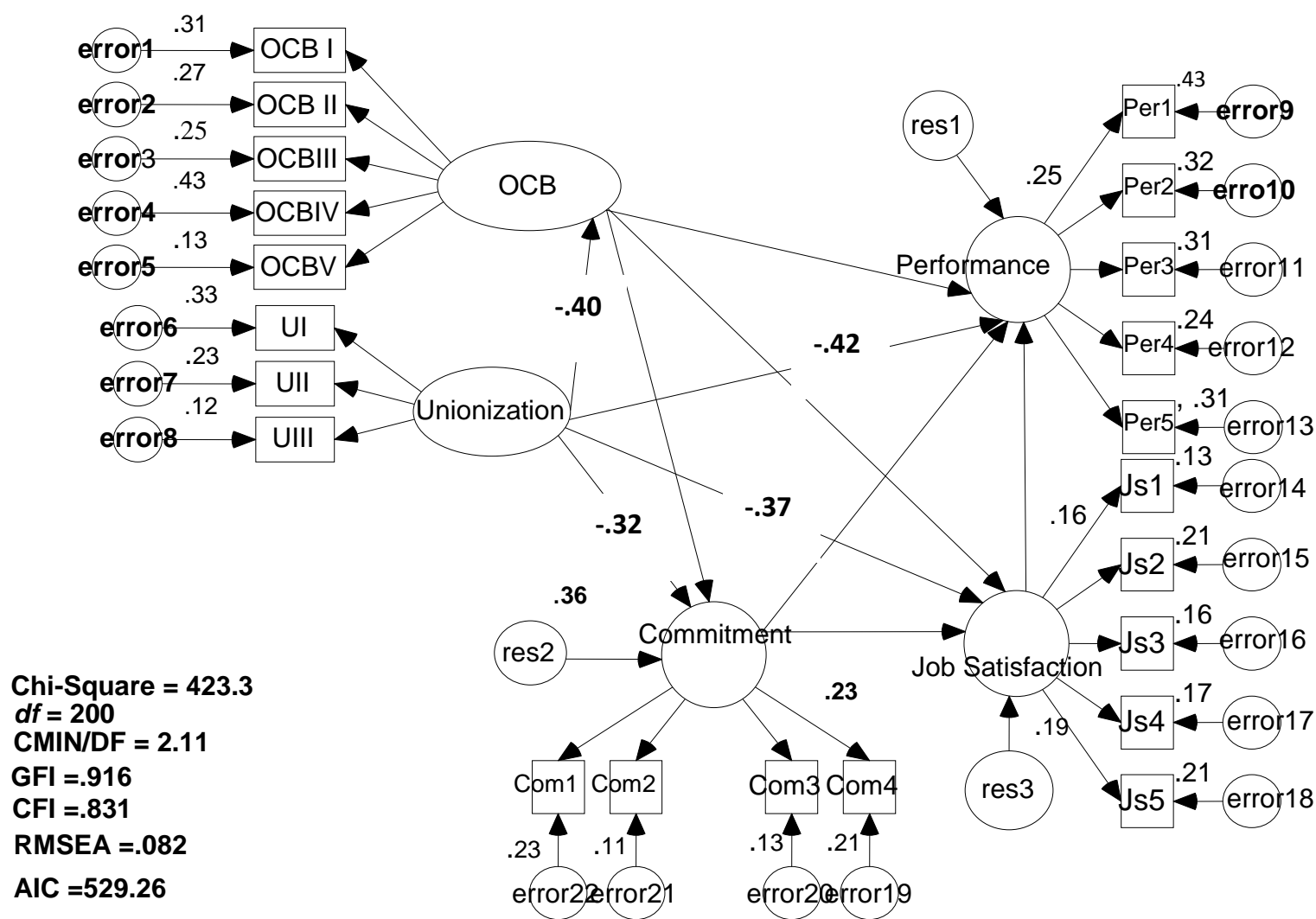

Fig. 1: Model for Direct Impact of Latent Variables

The model for testing the direct effect of unionization on employees' work related behavior, fitted data with acceptable level of model fit indices $(\chi 2=423.3, d f=200, \mathrm{CMIN} / d f=2.11$, $\mathrm{GFI}=.916, \mathrm{CFI}=.831, \mathrm{RMSEA}=.072$, and $\mathrm{AIC}=529.26$ ). The model indicates that direct effects flaws from unionization to employee outcomes can be reasonably established based on the data. Therefore, the results of the model tested can be utilized for testing the direct effect 
hypotheses of the study. The following table indicates both the standardized regression weights estimated for causal paths between the latent variables of the model.

Table 3: Estimated Standardized Regression Weights

\begin{tabular}{lcccccc}
\hline & & & Estimate & S.E & CR & P \\
Commitment & $<---$ & Unionization & -.321 & .103 & 3.587 & .000 \\
Job Satisfaction & $<---$ & Unionization & -.371 & .047 & 4.340 & .001 \\
Performance & $<---$ & Unionization & -.421 & .120 & 2.362 & .000 \\
OCB & $<---$ & Unionization & -.401 & .076 & 3.326 & .020 \\
\hline
\end{tabular}

Source: Data Analysis

\section{Effect of Unionization on Job Satisfaction}

It was assumed that unionization has a negative effect on job satisfaction of employees $\left(\mathrm{H}_{\mathbf{1}}\right)$. With the aim of testing this, a hypothesis was formulated in congruence with SEM terminology as $\left(\mathrm{H}_{1}\right)$ there is a negative effect of unionization on job satisfaction of employees in unionized work environment. This hypothesis postulates that unionization causes employees to be dissatisfied with their jobs. In other words, the higher the unionization of employees, the lower will be the job satisfaction of employees.

Hypothesis $\mathrm{H}_{1}$ that postulates that unionization has a negative effect on job satisfaction of employees, was supported. The results in Table 3 indicated a significant negative direct effect of unionization on job satisfaction of employees $(\beta=-.371, \mathrm{CR}=-4.340, \mathrm{p}<.05)$. This indicated that the effect of unionization on job satisfaction was more salient.

\section{Direct Effect of Unionization on Organizational Commitment}

Just like for job satisfaction and performance, the assumption was that organizational commitment of employees was associated negatively with unionization. Therefore, it hypothesized that $\left(\mathrm{H}_{2}\right)$ there is a negative impact of employee unionization on the organizational commitment of employees

According to the results of the direct path model tested, hypothesis $\mathrm{H}_{2}$ was supported because unionization had a negative impact on organizational commitment $(\beta=-.321, \mathrm{CR}=3.587$, $\mathrm{p}<.05)$. 


\section{Direct Effect of Unionization on Performance of Employees}

Based on the literature on employee unionization, it was assumed that there is a negative impact of employee unionization on the performance of employees. Therefore, it hypothesized that $\left(\mathrm{H}_{3}\right)$ there is a negative impact of employee unionization on performance of employees. With respect to the hypotheses $\mathrm{H}_{3}$, the data proved that employee unionization had a significant negative impact on performance of employees $(\beta=-.421, \mathrm{CR}=2.362, \mathrm{p}<.050)$. As a result, $\mathrm{H}_{3}$ was proven.

\section{Direct Effect of Unionization on OCB of Employees}

In this study, it was assumed that there is a negative impact of employee unionization on the OCB of employees. Therefore, it hypothesized that $\left(\mathrm{H}_{4}\right)$ there is a negative impact of employee unionization on OCB of employees. With respect to the hypotheses $\mathrm{H}_{4}$, the data proved that employee unionization had a significant negative impact on performance of employees $(\beta=$ $.401, \mathrm{CR}=3.326, \mathrm{p}<.050)$. As a result, $\mathrm{H}_{4}$ was proven.

\section{Findings and Discussion}

The results of the data analysis revealed that unionization has a significant negative effect on job satisfaction of employees in both public and private sector organizations in Sri Lanka. As a result, the objective of "to examine the effect of unionization on job satisfaction" of the study was achieved. The study found that unionization had a negative impact on job satisfaction of employee $(\beta=-.371, \mathrm{p}<.05)$ as postulated by the $\mathrm{H}_{1}$.

This finding of the study is in congruent with previous studies that union commitment affects negatively job satisfaction of employees (Hammer \& Avgar, 2005; Bengemin, 2010). This finding was congruent with the notion that employees who are commited to unions feel uncomfortable for being aligned with the organization and with the union simultanously (Redman \& Snape, 2012). The result of this discomfort would be a deviation of employees' efforts, attachement, and engagement from the organization to union (Goeddeke \& KammeyerMueller, 2010) reducing the level of job satisfaction of them. Further, this study found that unionization has a significant negative effect on organizational commitment employees supporting the $\mathrm{H}_{2}$ of the study $(\beta=-.321, \mathrm{CR}=3.587, \mathrm{p}<.05)$. This finding was supported by the finding of early studies too. With the fact that union commitment and organizational commitment are negatively related (Hammer \& Avgar, 2005; Bengemin, 2010), it can be 
infered that when the unionization of employees is high, they may be more commited to the union than the organization. The ultimate result of this would be the negative effect of uniuonization on organizational commitment. However, it has been evident in the union literature that organizational commitment (OC) and union commitment (UC) can be considered two distinct constructs operating simultaneously, which has been the basis for the dual commitment argument. As an example, Sherer and Morishima (1989) pointed out that organizational and union commitments are distinct constructs with different antecedents and can be seen as two distinct attitudes of employees. McElroy et al.(1997) further verified this stance. In this study, OCB of employee was found to be affected negatively by higher level of unionization of employees $(\beta=-.401, \mathrm{p}<.05)$. This was a support for the $\mathrm{H}_{4}$ of this study which states that there is a negative effect of unionization on OCB. Similar findings have been recorded in other studies.

It can reasonably be argued that union loyalty, one component of union commitment (Gordon, et al., 1980), may reduce the employee contextual performance in a cooperative labormanagement situation which is a one aspect of OCB. Further, this is congruent with the argument of Fuller and Hester (1998) that the non-significant association may be attributed to the fact that they had considered only one aspect of union commitment in their analysis. However, in a study with a survey data from both the United Kingdom and France, Bryson et al.(2009) provided evidence that unionization has an adverse effect on OCB in both countries. They further found that a higher level of union density had a more negative impact on performance in France than in the United Kingdom. Therefore, finding of a negative effect of unionization on OCB can be empiricaly suproted.

The main objective of this study was to assess the effect of unionization on organizational commitment, job satisfaction and OCB of employees in a unionized work environment. The study found that unionization has a significant negative impact on work related behaviors in a unionized work environment. It was found that unionization reduces the level of job satisfaction, OCB and organizational commitment of employees both in the public and private sector organizations. This can be attributed to the fact that union commitment which is one of the dimension of unionization was found to play a partial mediating role in a unionized work environment. This mediation may produce the negative effect as found in this study. On the other hand, union politicization which is another dimension of the unionization seems to be involving in producing a negative effect on work related behaviors. Given the fact that union politicization has a moderating effect (Hammer \& Avgar, 2005), it may produce a negative 
moderating effect so that unionization creates a negative effect on work related behaviors. This can be further verify with the finding of this study that unionization has a higher negative effect on work related behaviors in the public sector which is considered as one of the highly politicized work context, than the private sector.

As a specific objective, this study examined the effect of unionization on work related behaviors across the two sectors. It was hypothesized that there is a difference of the effect on unionization between the public and private sector. It was fond that unionization has a higher negative effect on work related behavior than in the private sector. This finding can be rationalized with the fact that unions in the public sector organizations are highly politicized compared to private sector unions (Dhammika, Ahamed, \& Sam, 2013). This may increase the negative effect of unionization to a significant degree in the public sector.

\section{Limitations}

The findings and conclusions of the present study have certain limitations. First, the study was carried out in selected private and public sector organizations in Sri Lanka. Since the sample of this study was not a holistically representative sample, findings can't be generalized to the entire private and public sector organizations in Sri Lanka. Second, the sample of the present study was consisted of only Clerical and Related Workers of the selected organizations Therefore, the findings may not be relevant to other occupational categories of the public sector of Sri Lanka and stand generalizable only to this occupation category. Third, this study is cross sectional in nature based on survey design. Therefore, the study has some of the weaknesses associated with a cross sectional study. For instance, the effects estimated in this study cannot be considered as the magnitude of fixed effect. Because accurate measurement of effect is not possible with cross sectional studies based on a survey, these effects estimated should be taken as sign of the size and the direction of association between the variables.

All variables involved in this study were measured on the response of the employees of the public sector organizations. Therefore, the measures of variables are perceived measures of the variables not objective measures. As a result, findings of this study should be viewed as a perceptual estimation of association between variables not as objective estimations. 


\section{References}

Aryce, S., \& Chay, Y. W. (2001). Workplace justice, citizenship behaviour, and turnover intentions in a union context: Examining the mediating effect role of percieved union support and union instrumentality. Journal of Applied Psychology, 86(1), 154-160. doi:10.1037/0021-9010.86.1.154

Barling, ,. J., Clive, F., \& Kelloway, E. K. (1992). The unions and its Memebrs: A psychlogical approach (Vol. 33). New York: Oxford University Press.

Belino, M., Harvey, J., Hsiung, H.-H., \& LePine, J. A. (2015). "Well I am Tired of Tryin"! Organizational citizenship behavior and citizenship fatigue. Journal of Applied Psychology, 100, 56-74.

Berkowitz. (1954). The economics of trade union organization and administration. Industrial and Labor Relations Review, 7(4), 575-592. doi:10.2307/2519105

Bryson, A., Lorenzo, C., \& Laidio, L. (2003). Does union memebership really reduce job satisfaction? London: Cetre for economic performance, London School of Economic. doi:10.1111/j.1467-8543.2004.00324.x

Cabral, R. (1992). Country Paper: Sri Lanka in Labour Management Relation: A key to productivity promotion. Tokyo: Asian Productivity Organization.

Charlwood, A. (2002). Why do non-union employees want to unionise: Evidence from Britin. British Journal of Industrial Relation, 40, 463-491. doi:10.1111/1467-8543.00243

Dhammika, K. A., Ahamed, F. B., \& Sam, T. L. (2013). Moderating effect of union politicization on leadership and employee outcomes relation: An empirical study on public sector organizations in Sri Lanka. International Conference in Business and Information (pp. 123-143). Colombo: University of Kelaniya. Retrieved from http://hdl.handle.net/123456789/13221

Dhammika, K. A., Ahmed, F. B., \& Sam, T. L. (2013). Assessment of the Goodness of Measure of Union Commitment: A Factorial Validation in Sri Lankan Context. Sri Lanka Journal of Advanced Social Studies, 2(2)., 2(2), 57-70. doi:10.4038/sljass.v2i2.6207

Dhammika, K. S. (2014). Organizational and union citizenship behavior: Are they unilateral or multilateral in Sri Lankan public sector context. Kelaniya Journal of Management, 2(2), 23-34. doi:10.4038/kjm.v2i2.6548

Doucouliagos, C., \& Loroche, P. (2009). Unions and profit: A meta-regression analysis. Industrial Relations, 48(9), 146-183.

Folger, R., \& Greenberg, J. (1985). Procedural justice: an interpretative analysis of personel system. In K. Rawland, \& G. Ferris, Research in Personnel and Human Resources management (Vol. 3, pp. 141-183). Greenwich:CT: JAI press. 
Freeman, R. B., \& Medoff, J. L. (1984). What do unions do. New York.

Fuller, J. B. (1998). The effect of labor relations climate on the union participation process. Journal of Labor Research, 19(1), 173-187. doi:10.1007/s12122-998-1009-Z

Goeddeke, F. X., \& Kammeyer-Mueller, J. D. (2010). Percievede support in a dual organizational enviornment: Union Participation in a university setting. Journal of Organizational Behavior, 31, 65-83.

Golden, T. D., \& Veiga, J. F. (2008). The impact of superior-subordinates relationship on the commitment, job satisfaction and performance of virtual wokers. The Leadership Quaterly, 19, 77-88.

Gordon, M. E., Philpot, J. W., Burt, R. E., Thompson, E. A., \& Spiller, W. E. (1980). Commitment to the union: Development of a Measure and an examination of its correlates. Journal of Applied Psychology, 65, 479-499.

Hammer, T. H., \& Avgar, A. (2005). The impact of unions on job satisfaction, organizational commitment and turnover. Journal of Labour Research, 16(2), 241-266.

Iverson, R. D., \& Kuruvilla, S. (1995). Antecedent of Union Loyalty: the influence of individual dispositions and organizational context. Journal of Organizational Behavior, 16, 557-582.

Jinadasa , P. V., \& Opatha, H. P. (1999). An empirical study of membership participation in trade union activities: evidence from selected service organizations in Sri Lanka. Sabaragamuwa University Journal, 2(1), 17-34.

John, W. B., Berger, C. J., \& Cregg, A. O. (1983). Effects on Union on job Satisfaction: The role of work related values and Percieved Rewards. Organizational Behaviour and Human Performance, 32(June), 289-324.

Kleiner, M. M. (2002). Intensitry of Management resistence: Understanding the decline of unionization in the private sector.

Kochan, T. A., \& David, E. H. (1981). The effect of collective Bargaining on economic and Behavioral job outcomes. Retrieved 11 13, 2010, from http://hdl.handle.net/1721.1/1978

Kochan, T. A., \& David, E. H. (1981). The effect of collective Bargaining on economic and Behavioral job outcomes.

Kumarashamy, Y. I., Amarasisri, A. D., Dalluwaththa, P., Ramyasisi, L. H., \& Guruge, O. G. (1997). A study on organizational Problems of Postal Department. Colombo: Sri Lanka Instituie of Development Administration (SLIDA). 
Laroche, P., \& Wechtler, H. (2011). The effect of labour union on work place performance: New evidence from France. Journal of Labour Research, 32(3), 157-180. doi:10.1007/s12122-011-9106-9

Liu, W., Guthrie, J. P., Flood, P., \& MaCcurtain, S. (2009). Union and the Adoptation of High Performance Work System: Do employment security play a role? Industrial and Labour Relation Journal, 63(1), 109-129. doi:10.1177/001979390906300106

McElroy, J. C., Morrow, R. C., \& Crum, M. R. (1997). Organizational and Union Commitment among Railroad employees. Logistics and Transpotaion Review, 33(3), 211-221. doi:10.1016/S1366-5545(97)00018-5

Meyer, J. P., Allen, N. J., \& Smith, C. A. (1993). Commitment to organizations and occupations: extention and test of a three-components conceptualization. Journal of applied psychology, 78, 538-551. doi:10.1037/0021-9010.78.4.538

Murillo, M. V., \& Ronconi, L. (2004). Teaches' Strikes in Agentina: Partisan allignment and publi-sector labour relation. Studies in Comparative International Development, 39(1), 77-98. doi:10.1007/BF02686316

O'Reilly, C. A., \& Chatman, J. (1981). Organizational commitment and psychological attachment: The effects of compliance, identification, and internalization on prosocial behavior. Journal of applied psychology,, 71(3), 492-499. doi:10.1037/00219010.71.3.492

Organ, D. W. (1997). Organizational citizenship behaviour: It's construct clean-up time. Human Performance, 10(2), 85-97. doi:10.1207/s15327043hup1002_2

Podsakoff , P. P., MacKenzie, , S. B., \& Moorman, R. H. (1990). Transformational leader behaviors and their effects on followers' trust in leader, satisfaction, and organizational citizenship behaviors. The Leadership Quaterly, 1(2), 107-142. doi:10.1016/1048-9843(90)90009-7

Shan, H., Hu, E., Zhi, L., Zhang, L., \& Zhang, M. (2016). Job satisfaction and employee's unionization decision: the mediating effect of percevied union instrumentality. Jouranl of Industrial Engineering and Management, 9(1), 110-122.

Sherer, P. D., \& Morishima, M. (1989). Roads and Roadblocks to dual commitment: similar and dissimilar antecedents of union and company commitment. Journal of Labour Research, 10, 311-330. doi:10.1007/BF02685274

Skorlicki, D. P., \& Latham, G. P. (1996). Increasing citizenship behavior within labour union: a test of organizational justice theory. Journal of Applied Psychology, 81(2), 161-169. doi:10.1037/0021-9010.81.2.161

Snape, E. D., \& Redman, T. . (2012). Industrial Relations Climate and Union Commitment: An Evaluation of Workplace-Level Effects. Industrial Relations: A Journal of Economy and Society,, 51(1), 11-28. doi:10.1111/j.1468-232X.2011.00662.x 
Stanger, R., \& Rosen, H. (1965). Psychology in union management relation. In J. G. Johnson, $\& \mathrm{R}$. W. Johnson, The effect of union membership on multiple work commitments among female public sector employees (pp. 181-191).

Thacker, R. A. (2015). The application of social exchange bonds of union employees: cognitive calculation of reciprocity. Human Resource Management Review, 25(3), 287-297. doi:10.1016/j.hrmr.2014.10.001

Whiting, S. W., Podsakoff, P. M., \& Pierce, J. R. (2008). Effect of task performance, helping, voice and organizational loyalty on performance appraisal ratings. Journal of Applied Psychology, 93, 125-139. doi:10.1037/0021-9010.93.1.125

William, L. J., \& Anderson, S. E. (1991). Job satisfaction and oganizational commitment as predictor of organizational citizen and in-role behavior. Journal of Management, 17(3), 601-617. doi:10.1177/014920639101700305 